DOI: https://10.15407/kvt197.03.020

UDC 517.977: 534.121.2

V.R. BARSEGHYAN, DSc (Phys. and Math.), Professor,

Leading Researcher of the Institute of Mechanics

of the National Academy of Sciences of Armenia,

Professor of the Faculty of Mathematics

and Mechanics of Yerevan State University

email: barseghyan@sci.am

Yerevan State University, Institute of Mechanics of NAS of Armenia

18, Bakunts st., 0033, Yerevan, Republic of Armenia

\title{
THE PROBLEM OF CONTROL OF MEMBRANE VIBRATIONS WITH NON-SEPARATED MULTIPOINT CONDITIONS AT INTERMEDIATE MOMENTS OF TIME
}

Introduction. Many control processes from various fields of science and technology lead to the necessity to study multipoint boundary value problems of control, in which, along with classical boundary conditions, non-separated multi-point intermediate conditions are also given. A characteristic feature of multipoint boundary value problems of control is the presence of non-separated conditions at several intermediate points of the study interval. Such control problems have important applied and theoretical value, a necessity naturally arises for their investigation in various settings. In this article, the problem of control of vibrations of a rectangular membrane with given initial, final conditions and non-separated values of the deflection function and velocities at intermediate moments of time is considered.

The purpose of the paper is to develop a constructive approach to construct a function of control action to control the vibrations of a rectangular membrane with given initial, final conditions and non-separated (non-local) values of the deflection and velocities of membrane points at intermediate moments of time.

Results. By the method of separation of variables, the problem is reduced to the problem of control of ordinary differential equations with given initial, final, and non-separated multipoint intermediate conditions. Using the methods of the theory of control of finitedimensional systems with multipoint intermediate conditions, a control action to control vibrations of a rectangular membrane is constructed.

Conclution. The problem of control of the vibrations of a rectangular membrane with given non-separated values of the deflection function and velocities at intermediate moments of time is solved by using the methods of the theory of control of finite-dimensional systems with multipoint intermediate conditions.

Keywords: control of vibrations, membrane vibration, intermediate values, non-separated multipoint conditions.

(c) V.R. BARSEGHYAN, 2019 


\section{INTRODUCTION}

One of the most common processes in nature and technology are oscillatory processes, which are modeled by the wave equations [1-4]. At the same time, in practice, control problems often arise when it is necessary to generate the desired vibration form that satisfies intermediate conditions. Many control processes lead to the necessity to study multipoint boundary value problems, in which, along with the classical boundary (initial and final) conditions, non-separated (non-local) multipoint intermediate conditions are given [5-15]. Non-separated multipoint boundary value problems, on the one hand, arise as mathematical models of real processes, and on the other hand, for many equations correct formulation of local boundary value problems is impossible. The nonseparability of multipoint conditions may be, in particular, due to the impossibility in practice to measure the parameters of the state of an object instantaneously or at its individual points.

Numerous examples of technological processes leading to the problems of control of systems with distributed parameters were considered in [1-3] and various methods of solutions were proposed. The control problems of oscillatory processes, with both external and boundary control actions under various types of boundary conditions are considered in [4, 7-14]. In [7-12] problems of control of vibrations of a string and membrane with given intermediate (local) states with the help of external forces acting on the systems were considered. The problems of control of distributed systems with given non-separated multipoint (non-local) conditions at intermediate moments of time are less explored to date.

The purpose of the paper is to develop a constructive approach to construct a function of control action for controlling vibrations of a rectangular membrane with given initial, final conditions and non-separated (non-local) deflection values and velocities of membrane points at intermediate times.

\section{THE FORMULATION OF THE PROBLEM}

Consider a homogeneous, elastic, rectangular membrane, the edges of which are fixed. Let distributed forces act on the membrane with a density $u(x, y, t)$ perpendicular to the surface of the membrane, under the action of which the membrane will vibrate. We restrict ourselves to the consideration of small vibrations of the membrane.

The state of the membrane is described by the function $Q(x, y, t)$, $0 \leq x \leq b, 0 \leq y \leq c, 0<t<T$, which for $0<x<b, 0<y<c$ и $0<t<T$ is characterized by the following equation:

$$
\frac{\partial^{2} Q}{\partial t^{2}}=a^{2}\left(\frac{\partial^{2} Q}{\partial x^{2}}+\frac{\partial^{2} Q}{\partial y^{2}}\right)+u(x, y, t)
$$

with homogeneous boundary conditions

$$
Q(0, y, t)=0, Q(b, y, t)=0, Q(x, 0, t)=0, Q(x, c, t)=0,0 \leq t \leq T
$$


and satisfying initial and final conditions

$$
\begin{gathered}
Q(x, y, 0)=\varphi_{0}(x, y),\left.\quad \frac{\partial Q}{\partial t}\right|_{t=0}=\psi_{0}(x, y), \quad 0 \leq x \leq b, \quad 0 \leq y \leq c, \\
Q(x, y, T)=\varphi_{T}(x, y)=\varphi_{m+1}(x, y),\left.\quad \frac{\partial Q}{\partial t}\right|_{t=T}=\psi_{T}(x, y)=\psi_{m+1}(x, y), \\
0 \leq x \leq b, \quad 0 \leq y \leq c .
\end{gathered}
$$

On the left hand side of equation (1) the function $u(x, y, t)$ - density of force, which is the control action, $a^{2}=\frac{T_{0}}{\rho}$, where $T_{0}$ - tension, and $\rho$ membrane density. It is assumed that the function $u(x, y, t) \in L_{2}(\Omega)$, where $\Omega=\{(x, y, t): x \in[0, b], y \in[0, c], t \in[0, T]\}$.

Let at some intermediate moments of time $0=t_{0}<t_{1}<\ldots<t_{m}<t_{m+1}=T$ on the values of the membrane deflection function non-separated (non-local) conditions are given in the following form:

$$
\begin{gathered}
\sum_{k=1}^{m} f_{k} Q\left(x, y, t_{k}\right)=\alpha(x, y), \\
\left.\sum_{k=1}^{m} e_{k} \frac{\partial Q(x, y, t)}{\partial t}\right|_{t=t_{k}}=\beta(x, y),
\end{gathered}
$$

where $f_{k}$ and $e_{k}$ - given values $(k=1, \ldots, m), \alpha(x, y)$ and $\beta(x, y)$ - some known functions.

Necessary condition for existence of the classical solution of the formulated problem (1)-(6) is a condition of compatibility of boundary, initial, intermediate and final conditions. Therefore it is supposed that $\varphi_{0}(x, y), \psi_{0}(x, y)$, $\varphi_{T}(x, y), \quad \psi_{T}(x, y), \alpha(x, y)$ and $\beta(x, y)$ are given smooth functions satisfying the compatibility conditions.

In general, it is possible that at some moments of time $t_{k}(k=1, \ldots, m)$ in the conditions (5), (6) either the values of the deflection function or values of derivatives of that function are present, i.e. it is not mandatory that at each moment of time $t_{k}(k=1, \ldots, m)$ in the conditions (5), (6) functions $Q\left(x, y, t_{k}\right)$ and $\left.\frac{\partial Q(x, y, t)}{\partial t}\right|_{t=t_{k}}$ are present at the same time. In those case we will consider that the corresponding coefficients $f_{k}$ or $e_{k}$ are equal to zero. In particular, assuming that $f_{2}=e_{1}=0$ and $f_{1}=e_{2}=1$, conditions (5) and (6) take the following form: 


$$
Q\left(x, y, t_{1}\right)=\alpha(x, y),\left.\frac{\partial Q(x, y, t)}{\partial t}\right|_{t=t_{2}}=\beta(x, y) .
$$

The control problem of membrane vibrations with given non-separated values of the deflection function and velocities at intermediate moments of time $t_{k}(k=1, \ldots, m)$ can be formulated as follows: among the possible controls $u(x, y, t), 0 \leq x \leq b, 0 \leq y \leq c, 0 \leq t \leq T$ it is required to find a control that transfers membrane vibrations (1) with boundary conditions (2) from a given initial state (3) to a given final state (4), ensuring the satisfaction of nonseparated multipoint intermediate conditions (5), (6).

It is assumed that system (1) with constraints (2) - (6) over the time interval $[0, T]$ is completely controllable $[5,16]$.

\section{THE SOLUTION OF THE PROBLEM}

To build a solution to the formulated problem, we are looking for a solution to the equation (1) with boundary conditions (2) in the following form:

$$
Q(x, y, t)=\sum_{k, n=1}^{\infty} Q_{k n}(t) \sin \frac{k \pi}{b} x \sin \frac{n \pi}{c} y .
$$

Apparently, to determine $Q(x, y, t)$ it suffices to determine $Q_{k n}(t)$, where $k, n=1,2, \ldots$ We represent the function $u(x, y, t)$ in the form of Fourier series

$$
u(x, y, t)=\sum_{k, n=1}^{\infty} u_{k m}(t) \sin \frac{k \pi}{b} x \sin \frac{n \pi}{c} y .
$$

Let us substitute decomposition (7), (8) into the relation (1). By virtue of the orthogonality of the system of eigenfunctions $\left\{\sin \frac{k \pi}{b} x \sin \frac{n \pi}{c} y\right\}$, where $k, n=1,2, \ldots$, it follows that coefficients of Fourier $Q_{k n}(t)$ satisfy the countable system of ordinary differential equations

$$
\begin{gathered}
\ddot{Q}_{k n}(t)+\lambda_{k n}^{2} Q_{k n}(t)=u_{k n}(t), \lambda_{k n}^{2}=a^{2}\left[\left(\frac{k \pi}{b}\right)^{2}+\left(\frac{n \pi}{c}\right)^{2}\right], \\
k, n=1,2, \ldots
\end{gathered}
$$

and the following initial, non-separated multipoint intermediate and final conditions:

$$
Q_{k n}(0)=\varphi_{k n}^{(0)}, \dot{Q}_{k n}(0)=\psi_{k n}^{(0)}
$$




$$
\begin{gathered}
\sum_{j=1}^{m} f_{j} Q_{k n}\left(t_{j}\right)=\alpha_{k n}, \sum_{j=1}^{m} e_{j} \dot{Q}_{k n}\left(t_{j}\right)=\beta_{k n}, \\
Q_{k n}(T)=\varphi_{k n}^{(T)}=\varphi_{k n}^{(m+1)}, \dot{Q}_{k n}(T)=\psi_{k n}^{(T)}=\psi_{k n}^{(m+1)},
\end{gathered}
$$

where $Q_{k n}(t), \varphi_{k n}^{(0)}, \psi_{k n}^{(0)}, \varphi_{k n}^{(m+1)}, \psi_{k n}^{(m+1)}, u_{k n}(t), \alpha_{k n}$ and $\beta_{k n}$ denote Fourier coefficients, corresponding to the functions $Q(x, y, t), \varphi_{0}(x, y), \psi_{0}(x, y)$, $\varphi_{m+1}(x, y), \psi_{m+1}(x, y), u(x, y, t), \alpha(x, y)$ and $\beta(x, y)$.

The general solution of equation (9) with initial conditions (10) and its time derivative have the following form:

$$
\begin{gathered}
Q_{k n}(t)=\varphi_{k n}^{(0)} \cos \lambda_{k n} t+\frac{1}{\lambda_{k n}} \psi_{k n}^{(0)} \sin \lambda_{k n} t+\frac{1}{\lambda_{k n}} \int_{0}^{t} u_{k n}(\tau) \sin \lambda_{k n}(t-\tau) d \tau, \\
\dot{Q}_{k n}(t)=-\lambda_{k n} \varphi_{k n}^{(0)} \sin \lambda_{k n} t+\psi_{k n}^{(0)} \cos \lambda_{k n} t+\int_{0}^{t} u_{k n}(\tau) \cos \lambda_{k n}(t-\tau) d \tau
\end{gathered}
$$

Now, taking into account the intermediate non-separated (11) and final (12) conditions using the approaches given in $[6,7]$, from equation (13), we obtain that the functions $u_{k n}(\tau)$ for each $k$ and $n$ must satisfy the following system of equalities:

$$
\begin{gathered}
\int_{0}^{T} u_{k n}(\tau) \sin \lambda_{k n}(T-\tau) d \tau=C_{1 k n}(T), \\
\int_{0}^{T} u_{k n}(\tau) \cos \lambda_{k n}(T-\tau) d \tau=C_{2 k n}(T), \\
\sum_{j=1}^{m} f_{j} \int_{0}^{t_{j}} u_{k n}(\tau) \sin \lambda_{k n}\left(t_{j}-\tau\right) d \tau=C_{1 k n}^{(m)}\left(t_{1}, \ldots, t_{m}\right), \\
\sum_{j=1}^{m} e_{j} \int_{0}^{t_{j}} u_{k n}(\tau) \cos \lambda_{k n}\left(t_{j}-\tau\right) d \tau=C_{2 k n}^{(m)}\left(t_{1}, \ldots, t_{m}\right),
\end{gathered}
$$

where

$$
\begin{gathered}
C_{1 k n}(T)=\lambda_{k n} \varphi_{k n}^{(m+1)}-\lambda_{k n} \varphi_{k n}^{(0)} \cos \lambda_{k n} T-\psi_{k n}^{(0)} \sin \lambda_{k n} T \\
C_{2 k n}(T)=\psi_{k n}^{(m+1)}+\lambda_{k n} \varphi_{k n}^{(0)} \sin \lambda_{k n} T-\psi_{k n}^{(0)} \cos \lambda_{k n} T \\
C_{1 k n}^{(m)}\left(t_{1}, \ldots, t_{m}\right)=\lambda_{k n}\left[\alpha_{k n}-\sum_{j=1}^{m} f_{j}\left(\varphi_{k n}^{(0)} \cos \lambda_{k n} t_{j}+\frac{1}{\lambda_{k n}} \psi_{k n}^{(0)} \sin \lambda_{k n} t_{j}\right)\right], \\
C_{2 k n}^{(m)}\left(t_{1}, \ldots, t_{m}\right)=\beta_{k n}-\sum_{j=1}^{m} e_{j}\left(-\lambda_{k n} \varphi_{k n}^{(0)} \sin \lambda_{k n} t_{j}+\psi_{k n}^{(0)} \cos \lambda_{k n} t_{j}\right) .
\end{gathered}
$$


We introduce the following functions

$$
\begin{aligned}
& h_{1 k n}(\tau)=\sin \lambda_{k n}(T-\tau), h_{2 k n}(\tau)=\cos \lambda_{k n}(T-\tau), 0 \leq \tau \leq T \\
& h_{1 k n}^{(m)}(\tau)=\sum_{j=1}^{m} f_{j} h_{1 k n}^{(j)}(\tau) \\
& h_{1 k n}^{(j)}(\tau)=\left\{\begin{array}{l}
\sin \lambda_{k n}\left(t_{j}-\tau\right) \text { when } 0 \leq \tau \leq t_{j}, \\
0 \quad \text { when } t_{j}<\tau \leq t_{m+1}=T,
\end{array}\right. \\
& h_{2 k n}^{(m)}(\tau)=\sum_{j=1}^{m} e_{j} h_{2 k n}^{(j)}(\tau), \\
& h_{2 k n}^{(j)}(\tau)= \begin{cases}\cos \lambda_{k n}\left(t_{j}-\tau\right) & \text { when } 0 \leq \tau \leq t_{j}, \\
0 \quad & \text { when } t_{j}<\tau \leq t_{m+1}=T .\end{cases}
\end{aligned}
$$

Then the integral relations (14) with the help of the function (16) are written as follows:

$$
\begin{gathered}
\int_{0}^{T} u_{k n}(\tau) h_{1 k n}(\tau) d \tau=C_{1 k n}(T), \int_{0}^{T} u_{k n}(\tau) h_{2 k n}(\tau) d \tau=C_{2 k n}(T), \\
\int_{0}^{T} u_{k n}(\tau) h_{1 k n}^{(m)}(\tau) d \tau=C_{1 k n}^{(m)}\left(t_{1}, \ldots, t_{m}\right), \int_{0}^{T} u_{k n}(\tau) h_{2 k n}^{(m)}(\tau) d \tau=C_{2 k n}^{(m)}\left(t_{1}, \ldots, t_{m}\right), \\
k, n=1,2, \ldots .
\end{gathered}
$$

Thus, the required functions $u_{k n}(\tau), \tau \in[0, T]$, for each $k$ and $n$ must satisfy the integral relations (17).

Using the following notation

$$
H_{k n}(\tau)=\left(\begin{array}{c}
h_{1 k n}(\tau) \\
h_{2 k n}(\tau) \\
h_{1 k n}^{(m)}(\tau) \\
h_{2 k n}^{(m)}(\tau)
\end{array}\right), \eta_{k n}=\left(\begin{array}{c}
C_{1 k n}(T) \\
C_{2 k n}(T) \\
C_{1 k n}^{(m)}\left(t_{1}, \ldots, t_{m}\right) \\
C_{2 k n}^{(m)}\left(t_{1}, \ldots, t_{m}\right)
\end{array}\right)
$$

we re-write integral relations (17) in the form:

$$
\int_{0}^{T} H_{k n}(t) u_{k n}(t) d t=\eta_{k n} .
$$

From relation (19) (or (17)) it follows that for each harmonic, the motion described by equation (9) with conditions (10) - (12) is completely controllable if and only if for any given vector $\eta_{k n}(18)$ it is possible to find a control $u_{k n}(t)$, $t \in[0, T]$, satisfying condition (19) (or (17)). 
We introduce notation

$$
S_{k n}=\int_{0}^{T} H_{k n}(t)\left(H_{k n}(t)\right)^{T} d t=\left(\begin{array}{cccc}
s_{11}^{(k n)} & s_{12}^{(k n)} & s_{13}^{(k n)} & s_{14}^{(k n)} \\
s_{21}^{(k n)} & s_{22}^{(k n)} & s_{23}^{(k n)} & s_{24}^{(k n)} \\
s_{31}^{(k n)} & S_{32}^{(k n)} & s_{33}^{(k n)} & s_{34}^{(k n)} \\
s_{41}^{(k n)} & S_{42}^{(k n)} & s_{43}^{(k n)} & s_{44}^{(k n)}
\end{array}\right),
$$

where $H_{k n}(t)\left(H_{k n}(t)\right)^{T}$ - outer product of vectors. Henceforth the letter «T» in the superscript denotes transpose operation.

Let's assume that $\operatorname{det} S_{n} \neq 0$. Then, following [5, 17], for each $k, n=1,2, \ldots$ the function $u_{k n}(t), t \in[0, T]$, satisfying the integral relation (19), can be written as

$$
u_{k n}(t)=\left(H_{k n}(t)\right)^{T} S_{k n}^{-1} \eta_{k n}+v_{k n}(t)
$$

where $v_{k n}(t)$ - some vector function such that

$$
\int_{0}^{T} H_{k n}(t) v_{k n}(t) d t=0 .
$$

The elements of the matrix $S_{n}$, according to (20) and the notation (16), (18), have the following forms:

$$
\begin{gathered}
s_{11}^{(k n)}=\int_{0}^{T}\left(h_{1 k n}(\tau)\right)^{2} d \tau=\int_{0}^{T}\left(\sin \lambda_{k n}(T-\tau)\right)^{2} d \tau, \\
s_{12}^{(k n)}=s_{21}^{(k n)}=\int_{0}^{T} h_{1 k n}(\tau) h_{2 k n}(\tau) d \tau=\int_{0}^{T} \sin \lambda_{k n}(T-\tau) \cos \lambda_{k n}(T-\tau) d \tau, \\
s_{13}^{(k n)}=s_{31}^{(k n)}=\int_{0}^{T} h_{1 k n}(\tau) h_{1 k n}^{(m)}(\tau) d \tau=\int_{0}^{T} \sin \lambda_{k n}(T-\tau)\left(\sum_{j=1}^{m} f_{j} h_{1 k n}^{(j)}(\tau)\right) d \tau, \\
s_{14}^{(k n)}=s_{41}^{(k n)}=\int_{0}^{T} h_{1 k n}(\tau) h_{2 k n}^{(m)}(\tau) d \tau=\int_{0}^{T} \sin \lambda_{k n}(T-\tau)\left(\sum_{j=1}^{m} e_{j} h_{2 k n}^{(j)}(\tau)\right) d \tau= \\
=\sum_{j=1}^{m} e_{j} \int_{0}^{T} \sin \lambda_{k n}(T-\tau) h_{2 k n}^{(j)}(\tau) d \tau=\sum_{j=1}^{m} e_{j} \int_{0}^{t_{j}} \sin \lambda_{k n}(T-\tau) \cos \lambda_{k n}\left(t_{j}-\tau\right) d \tau, \\
s_{23}^{(k n)}=s_{32}^{(k n)}=\int_{0}^{T} h_{2 k n}(\tau) h_{1 k n}^{(m)}(\tau) d \tau=\int_{0}^{T} \cos \lambda_{k n}(T-\tau)\left(\sum_{j=1}^{m} f_{j} h_{1 k n}^{(j)}(\tau)\right) d \tau,
\end{gathered}
$$




$$
\begin{gathered}
s_{22}^{(k n)}=\int_{0}^{T}\left(h_{2 k n}(\tau)\right)^{2} d \tau=\int_{0}^{T}\left(\cos \lambda_{k n}(T-\tau)\right)^{2} d \tau, \\
s_{24}^{(k n)}=s_{42}^{(k n)}=\int_{0}^{T} h_{2 k n}(\tau) h_{2 k n}^{(m)}(\tau) d \tau=\int_{0}^{T} \cos \lambda_{k n}(T-\tau)\left(\sum_{j=1}^{m} e_{j} h_{2 k n}^{(j)}(\tau)\right) d \tau= \\
=\sum_{j=1}^{m} e_{j} \int_{0}^{T} \cos \lambda_{k n}(T-\tau) h_{2 k n}^{(j)}(\tau) d \tau=\sum_{j=1}^{m} e_{j} \int_{0}^{t_{j}} \cos \lambda_{k n}(T-\tau) \cos \lambda_{k n}\left(t_{j}-\tau\right) d \tau, \\
S_{33}^{(k n)}=\int_{0}^{T}\left(h_{1 k n}^{(m)}(\tau)\right)^{2} d \tau=\int_{0}^{T}\left(\sum_{j=1}^{m} f_{j} h_{1 k n}^{(j)}(\tau)\right)^{2} d \tau, \\
s_{34}^{(k n)}=s_{43}^{(k n)}=\int_{0}^{T} h_{1 k n}^{(m)}(\tau) h_{2 k n}^{(m)}(\tau) d \tau=\int_{0}^{T}\left(\sum_{j=1}^{m} f_{j} h_{1 k n}^{(j)}(\tau)\right)\left(\sum_{j=1}^{m} e_{j} h_{2 k n}^{(j)}(\tau)\right) d \tau, \\
s_{0}^{T}\left(h_{2 k n}^{(m)}(\tau)\right)^{2} d \tau=\int_{0}^{T}\left(\sum_{j=1}^{m} e_{j} h_{2 k n}^{(j)}(\tau)\right)^{2} d \tau .
\end{gathered}
$$

Note that, according to the notation (16), we will have

$$
\begin{aligned}
& h_{1 k n}^{(m)}(t)=\left\{\begin{array}{cc}
\sum_{j=1}^{m} f_{j} \sin \lambda_{k n}\left(t_{j}-t\right), & 0 \leq t \leq t_{1}, \\
\sum_{j=2}^{m} f_{j} \sin \lambda_{k n}\left(t_{j}-t\right), & t_{1}<t \leq t_{2} \\
\ldots & \\
\sum_{j=m-1}^{m} f_{j} \sin \lambda_{k n}\left(t_{j}-t\right), & t_{m-2}<t \leq t_{m-1} \\
f_{m} \sin \lambda_{k n}\left(t_{m}-t\right), & t_{m-1}<t \leq t_{m} \\
0, & t_{m}<t \leq t_{m+1}=T
\end{array},\right. \\
& h_{2 k n}^{(m)}(t)=\left\{\begin{array}{cc}
\sum_{j=1}^{m} e_{j} \cos \lambda_{k n}\left(t_{j}-t\right), & 0 \leq t \leq t_{1} \\
\sum_{j=2}^{m} e_{j} \cos \lambda_{k n}\left(t_{j}-t\right), & t_{1}<t \leq t_{2} \\
\ldots & t_{m-1}<t \leq t_{m} \\
\sum_{j=m-1}^{m} e_{j} \cos \lambda_{k n}\left(t_{j}-t\right), & t_{m-2}<t \leq t_{m-1} \\
e_{m} \cos \lambda_{k n}\left(t_{m}-t\right), & t_{m}<t \leq t_{m+1}=T \\
0, &
\end{array} .\right.
\end{aligned}
$$


Therefore, taking into account the notation (16) and (18), the control action $u_{k n}(t), t \in[0, T]$, according to $(21)$, is represented in the following form:

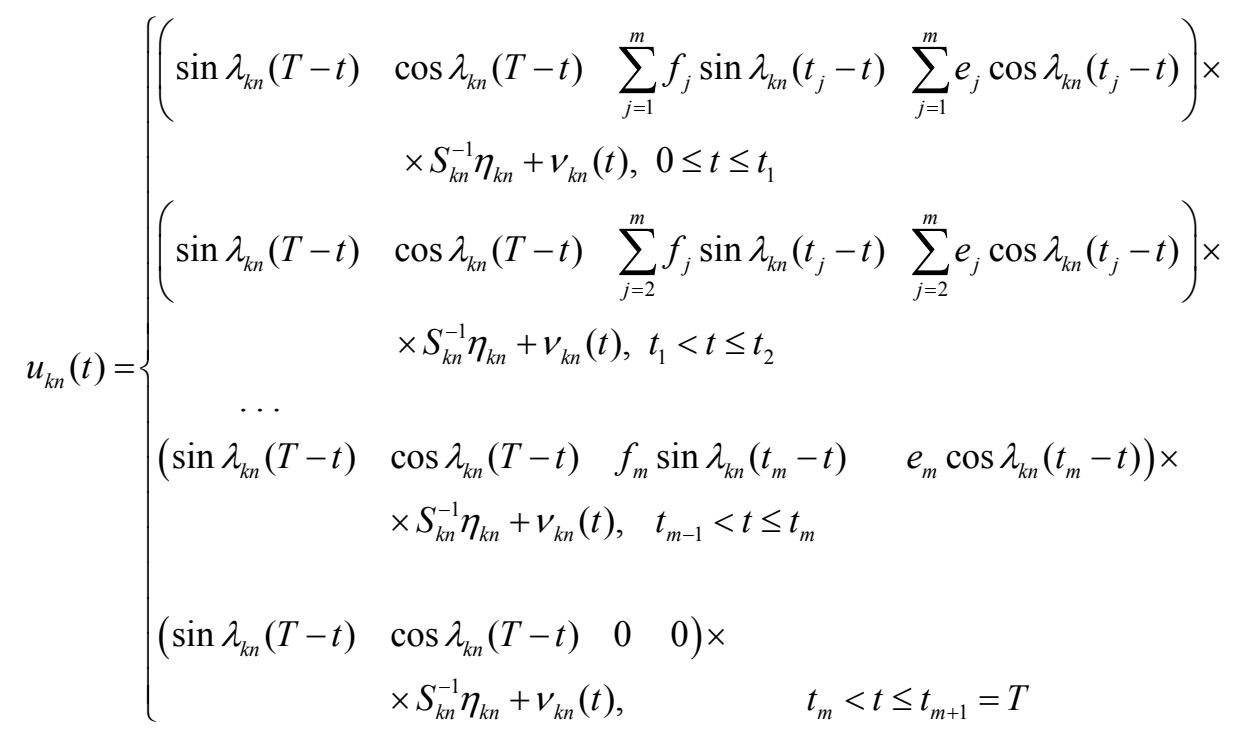

Substituting the obtained expressions $u_{k n}(t)$ into (13), we obtain $Q_{k n}(t)$ on the time interval $t \in[0, T]$, and from formulas (7) and (8) we obtain the functions of the deflection, $Q(x, y, t)$, and control, $u(x, y, t)$. Thus, the explicit expressions for the control function $u(x, y, t)$ have the form:

for $0 \leq t \leq t_{1}$

$$
\begin{aligned}
& u(x, y, t)=
\end{aligned}
$$

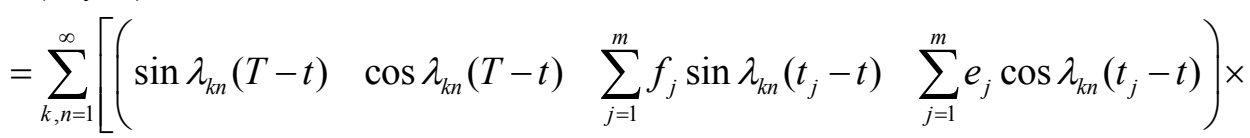

$$
\begin{aligned}
& \left.\times S_{k n}^{-1} \eta_{k n}+v_{k n}(t)\right] \sin \frac{k \pi}{b} x \sin \frac{n \pi}{c} y,
\end{aligned}
$$

for $t_{1}<t \leq t_{2}$

$$
\begin{aligned}
& u(x, y, t)= \\
& =\sum_{k, n=1}^{\infty}\left[\left(\begin{array}{ll}
\sin \lambda_{k n}(T-t) & \left.\cos \lambda_{k n}(T-t) \sum_{j=2}^{m} f_{j} \sin \lambda_{k n}\left(t_{j}-t\right) \sum_{j=2}^{m} e_{j} \cos \lambda_{k n}\left(t_{j}-t\right)\right) \times \\
\left.\times S_{k n}^{-1} \eta_{k n}+v_{k n}(t)\right] \sin \frac{k \pi}{b} x \sin \frac{n \pi}{c} y,
\end{array}\right.\right.
\end{aligned}
$$

for $t_{m-1}<t \leq t_{m}$ $u(x, y, t)=$ 


$$
\begin{gathered}
=\sum_{k, n=1}^{\infty}\left[\left(\sin \lambda_{k n}(T-t) \quad \cos \lambda_{k n}(T-t) \quad f_{m} \sin \lambda_{k n}\left(t_{m}-t\right) \quad e_{m} \cos \lambda_{k n}\left(t_{m}-t\right)\right) \times\right. \\
\left.\times S_{k n}^{-1} \eta_{k n}+v_{k n}(t)\right] \sin \frac{k \pi}{b} x \sin \frac{n \pi}{c} y,
\end{gathered}
$$

for $t_{m}<t \leq t_{m+1}=T$

$$
\begin{aligned}
& u(x, y, t)= \\
& =\sum_{k, n=1}^{\infty}\left[\left(\begin{array}{llll}
\sin \lambda_{k n}(T-t) & \cos \lambda_{k n}(T-t) & 0 & 0
\end{array}\right) S_{k n}^{-1} \eta_{k n}+v_{k n}(t)\right] \sin \frac{k \pi}{b} x \sin \frac{n \pi}{c} y .
\end{aligned}
$$

Thus, having explicit expressions for the control function (which is a piecewise continuous function), using the above formulas, the deflection function of the membrane can be found.

\section{CONCLUSION}

In this article the problem of control of the vibrations of a rectangular membrane with given non-separated values of the deflection function and velocities at intermediate moments of time by the method of separation of variables, is reduced to the problem of control of countable ordinary differential equations with given initial, final, and non-separated multipoint intermediate conditions. The solution to the problem is constructed by using the methods of the theory of control of finite-dimensional systems with multipoint intermediate conditions.

\section{REFERENCES}

1. Butkovskiy A.G. Methods of the systems control with distributed parameters. Moscow: Nauka. 1975. (in Russian).

2. Sirazetdinov T.K. Systems optimization with distributed parameters. Moscow: Nauka. 1977. (in Russian)

3. Znamenskaya, L.N. Control of elastic vibrations. Moscow: FIZMATLIT. 2004. (in Russian)

4. Kopets M.M. Optimal control of vibrations of a rectangular membrane. Kibernetika $i$ vyčislitelnaâ tehnika. 2014. Iss. 177, pp. 28-42. (in Russian).

5. Barseghyan V.R. Control of Compound Dynamic Systems and of Systems with Multipoint Intermediate Conditions. Moscow: Nauka. 2016. (in Russian).

6. Barseghyan V.R. and Barseghyan T.V. On an Approach to the Problems of Control of Dynamic System with Nonseparated Multipoint Intermediate Conditions. Automation and Remote Control, 2015, Vol. 76, no 4, pp. 549-559.

7. Barseghyan V.R., Saakyan, M. A. The optimal control of wire vibration in the states of the given intermediate periods of time. Proc. of NAS RA: Mechanics, 2008, 61(2), pp. 52-60. (in Russian)

8. Barseghyan V.R. Optimal control of a membrane vibration with fixed intermediate states. Proceedings of YSU. 1998. 188 (1), pp. 24-29. (in Russian).

9. Barseghyan V.R. On the problem of boundary control of string oscillations with given states at intermediate moments of time. Proceedings The XIth All-Russian Congress on Basic Problems of Theoretical and Applied Mechanics (Kazan, 20-24 $4^{\text {th }}$ of Aug, 2015), Kazan, 2015, part 1, pp. 354-356. (in Russian).

10. Barseghyan V.R. About one problem of optimal boundaery control of string vibrations with restrictions in the intermediate moment of time. Proceedings of the 11th International Chetaev Conference. Analytical mechanics, stability and control (Kazan, $14-18^{\text {th }}$ of June, 2017). Kazan, 2017. Vol. 3, part 1, pp. 119-125. (in Russian). 
11. Korzyuk V.I., Kozlovskia I.S. Two-point boundary problem for the equation of string vibration with the given velocity at the certain moment of time. Proceedings of the Institute of Math. NAS of Belarus. 2010. 18(2), pp. 22-35. (in Russian).

12. Korzyuk V.I., Kozlovskia I.S. Two-point boundary problem for the equation of string vibration with the given velocity at the certain moment of time. Proceedings of the Institute of Math. NAS of Belarus. 2010. 19(1). pp. 62-70. (in Russian).

13. Makarov A.A., Levkin D.A. Multipoint boundary value problemfor pseudodierential equations in multilayer. Vistnyk of V.N. Karazin Kharkiv National University. Ser. Mathematics, Applied Mathematics and Mechanics. 2014. № 1120. Vol. 69, pp. 64-74. (in Ukrainian).

14. Assanova A.T., Imanchiev A.E On the solvability of a nonlocal boundary value problem for a loadedhyperbolic equations with multi-point conditions. Bulletin of the Karaganda University. Series: Mathematics. 2016, no 1 (81), pp. 15-20. (in Russian).

15. Bakirova E.A., Kadirbayeva Zh.M. On a Solvability of Linear Multipoint Boundary Value Problem for the Loaded Differential Equations. Izvestiya NAS RK. Ser. fiz.-mat., 2016, Vol. 5, no 309, pp. 168-175. (in Russian).

16. Krasovsky N.N. The Theory of Motion Control. Moscow: Nauka. 1968. (in Russian).

17. Zubov V.I. Lectures on the Theory of Control. Moscow: Nauka. 1975. (in Russian).

\section{ЛITEPAТУРА}

Received 06.05.2019

1. Бутковский А.Г. Методы управления системами с распределенными параметрами М.: Наука, 1975. 568 с.

2. Сиразетдинов Т.К. Оптимизация систем с распределенными параметрами М.: Наука, 1977. 480 с.

3. Знаменская Л.Н. Управление упругими колебаниями М.: ФИЗМАТЛИТ, 2004. 176 с.

4. Копец М.М. Оптимальное управление колебаниями прямоугольной мембраны. Кибернетика и вычислительная техника. 2014. Вып. 177. С. 28-42.

5. Барсегян В.Р. Управление составных динамических систем и систем с многоточечными промежуточными условиями М.: Наука, 2016. 230 с.

6. Барсегян В.Р., Барсегян Т.В. Об одном подходе к решению задач управления динамических систем с неразделенными многоточечными промежуточными условиями Автоматика и телемеханика. 2015. № 4. С. 3-15.

7. Барсегян В.Р., Саакян М.А. Оптимальное управление колебаниями струны с заданными состояниями в промежуточные моменты времени Известия НАН РА. Механика. 2008. Т. 61. № 2. С. 52-60.

8. Барсегян В.Р. Об оптимальном управлении колебаниями мембраны при фиксированных промежуточных состояниях Уч. записки ЕГУ. 1998. № 1(188). С. 24-29.

9. Барсегян В.Р. О задаче граничного управления колебаниями струны с заданными состояниями в промежуточные моменты времени XI Всероссийский съезд по фундаментальным проблемам теоретической и прикладной механики. Сборник докладов, (Казань, 20-24 августа, 2015). Казань, 2015. С. 354-356.

10. Барсегян В.Р. Об одной задаче граничного оптимального управления колебаниями струны с ограничениями в промежуточные моменты времени «Аналитическая механика, устойчивость и управление»: труды ХІ Международной Четаевской конференции. Т. 3. Ч. І. (Казань, 13-17 июня, 2017). Казань, 2017. С. 119-125.

11. Корзюк В.И., Козловская И.С. Двухточечная граничная задача для уравнения колебания струны с заданной скоростью в некоторый момент времени. I Труды Инта мат. НАН Беларуси. 2010. Т. 18. № 2. С. 22-35.

12. Корзюк В.И., Козловская И.С. Двухточечная граничная задача для уравнения колебания струны с заданной скоростью в некоторый момент времени. II Tpyды Инта мат. НАН Беларуси. 2011. Т. 19. № 1. С. 62-70.

13. Макаров А.А., Левкин Д.А. Многоточечная краевая задача для псевдодифференциальных уравнений в полислое Вісн. ХНУ ім. В.Н. Каразіна. Серія: Математика, прикладна математика і механіка. 2014. № 1120. Вып. 69. С. 64-74. 
14. Асанова А.Т., Иманчиев А.Е. О разрешимости нелокальной краевой задачи для нагруженных гиперболических уравнений с многоточечными условиями Becm. Карагандинского университета. Серия: Математика. 2016. № 1(81). С. 15-20.

15. Бакирова Э.А., Кадирбаева Ж.М. О разрешимости линейной многоточечной краевой задачи для нагруженных дифференциальных уравнений Изв. НАН РК. Сер. физ.-мат. 2016. № 5. С. 168-175.

16. Красовский Н.Н. Теория управления движением М.: Наука, 1968. 476 с.

17. Зубов В.И. Лекции по теории управления М.: Наука, 1975. 496 с.

Отримано: 06.05.2019

B.P. Барсегян, д-р фіз.-мат. наук, проф., провід. наук. співроб. Інститута механіки НАН Вірменії, професор факультету математики і механіки Єреванського державного університету email: barseghyan@sci.am Єреванський державний університет, Інститут механіки НАН Вірменії вул. Бакунца, 8, м. Єреван, 0033, Республіка Вірменія

\section{ЗАВДАННЯ КЕРУВАННЯ КОЛИВАННЯМИ МЕМБРАНИ 3 НЕРОЗДІЛЕНИМИ БАГАТОТОЧКОВИМИ УМОВАМИ У ПРОМІЖНІ МОМЕНТИ ЧАСУ}

Вступ. Характерною особливістю багатоточкових крайових задач контролю $є$ наявність нерозділених умов у кількох проміжних точках інтервалу дослідження. Такі проблеми керування мають важливе прикладне і теоретичне значення, природно виникає необхідність їхнього дослідження в різних умовах. У статті розглянуто проблему контролю коливань прямокутної мембрани із заданими початковими, кінцевими умовами та нерозділеними значеннями функції перегину та швидкостей у проміжні моменти часу.

Метою статті є розроблення конструктивного підходу до побудови функції керувальної дії для контролю коливань прямокутної мембрани із заданими початковими, кінцевими умовами та нерозділеними (не локальними) значеннями перегину та швидкостями мембранних точок в проміжні моменти часу.

Результати. Методом поділу змінних задача зводиться до задачі керування звичайними диференціальними рівняннями із заданими початковими, кінцевими та нерозділеними багатоточковими проміжними умовами. За допомогою методів теорії керування кінцевомірними системами з багатоточковими проміжними умовами побудовано керувальну дію для контролю коливань прямокутної мембрани.

Висновки. Задача керування коливаннями прямокутної мембрани із заданими нерозділеними значеннями функції відхилення та швидкостей у проміжні моменти часу вирішується за допомогою методів теорії керування кінцево-розмірними системами 3 багатоточковими проміжними умовами.

Ключові слова: керування коливаннями, коливання мембрани, проміжні значення, нерозділені багатоточкові умови 
B.P. Барсегян, д-р физ.-мат. наук, проф., вед. науч. сотр. Института механики НАН Армении, профессор факультета математики и механіки Ереванского государственного университета. email: barseghyan@sci.am

Ереванский государственный университет, Институт механики НАН Армении ул. Бакунца, 8, г. Ереван, 0033, Республика Армения

\section{ЗАДАЧА УПРАВЛЕНИЯ КОЛЕБАНИЯМИ МЕМБРАНЫ \\ С НЕРАЗДЕЛЕННЫМИ МНОГОТОЧЕЧНЫМИ УСЛОВИЯМИ В ПРОМЕЖУТОЧНЫЕ МОМЕНТЫ ВРЕМЕНИ}

Рассмотрена задача управления колебаниями прямоугольной мембраны с заданными неразделенными значениями функции прогиба и скоростей в промежуточные моменты времени. Методом разделения переменных проблема сводится к задаче управления обыкновенных дифференциальных уравнений с заданными начальными, конечными и неразделенными многоточечными промежуточными условиями. Используя методы теории управления конечномерными системами с многоточечными промежуточными условиями, построено управляющее воздействие.

Ключевые слова: управление колебаниями, колебание мембраны, промежуточные значения, неразделенные многоточечные условия. 